\title{
The Effect of glutathione contents of White Ginseng(WG) Extracts and Entomopathogenic Fugi Extracts on the liver in Mice that was irradiated by radiation
}

\author{
Inho $\mathrm{Ko}^{*}$, Jindong Yeo** \\ Dept. of Radiological Technology, Cheju Halla University ${ }^{*}$, Dept. of Radiological Technology, Sorabol University ${ }^{* *}$

\section{동충하초 추출물과 백삼추출물 투여가 방사선을 조사한 생쥐 간에서의 glutathione함량에 미치는 영향}

\author{
고인호*, 여진동** \\ 제주한라대학교 방사선과*, 서라벌대학교 방사선과 ${ }^{* *}$
}

\begin{abstract}
The radioprotective effects of white ginseng and Entomopathogenic Fugi Extract on liver damage induced by $\times$-ray were investigated. To one group of ICR male mice were given white ginseng $(150 \mathrm{mg} / \mathrm{kg} / \mathrm{day}$ for 7 days, orally) and Entomopathogenic Fugi $(200 \mathrm{mg} / \mathrm{kg} /$ day for 7 days, orally $)$ before $\times$-ray irradiation. To another group were irradiated by $5 \mathrm{~Gy}(1.01 \mathrm{~Gy} / \mathrm{min})$ dose of $\times$-ray. Contrast group were given with saline $(0.1 \mathrm{ml})$. The levels of reduced(GSH) and oxidized(GSSG) glutathione in liver tissue were measured.

The ratio of GSSG/total GSH was significantly decreased in the white ginseng and Entomopathogenic Fugi $(200 \mathrm{mg} / \mathrm{kg} /$ day $)(150 \mathrm{mg} / \mathrm{kg} /$ day $)$ groups than irradiation group.
\end{abstract}

key words : X-ray, GSH, GSSG, Entomopathogenic Fugi, white ginseng

\section{요 야}

본 연구는 선형가속기의 고에너지 엑스선을 조사한 생쥐 간에 대한 백삼과 동충하초의 방사선방호효과를 연구하였 다. ICR계 수컷생쥐 군에 7일 동안에 경구적으로 백삼 $(150 \mathrm{mg} / \mathrm{kg} / \mathrm{day})$ 과 동충하초 $(200 \mathrm{mg} / \mathrm{kg} / \mathrm{day})$ 를 각각 방사선 조사 전에 투여했고 다른 생쥐 군에 $5 \mathrm{~Gy}(1.01 \mathrm{~Gy} / \mathrm{min})$ 의 방사선량으로 전신조사를 했고 대조군에 생리적 식염수 $(0.1 \mathrm{ml})$ 를 투여 한 후 간 조직에서 환원형 글루타치온 $(\mathrm{GSH})$ 과 산화형 글루타치온(GSSG)의 함량을 각각 검사하였 다. 그 결과 방사선조사군 $(\mathrm{Rad})$ 보다 동충하초투여군 $(\mathrm{EF}+\mathrm{Rad})$ 과 백삼투여군 $(\mathrm{WG}+\mathrm{Rad})$ 에서 환원형 글루타치온 (GSH)함량이 유의성 있게 증가했으나 산화형 글루타치온(GSSG)의 함량은 유의성 있게 감소하였다. 총 환원형 글루 타치온(total GSH)과 산화형 글루타치온(GSSG)의 함량 비율은 방사선조사군(Rad)보다 동충하초투여군(EF+Rad)과 백삼투여군 $(\mathrm{WG}+\mathrm{Rad})$ 에서 유의성 있게 감소하였다.

중심단어: 엑스선, 환원형 글루타치온(GSH), 산화형 글루타치온(GSSG), 동충하초투여군(EF+Rad), 백삼 


\section{I. 서 론}

호기성 생물체에서는 산소호흡이 생존에 필수적이 며 이로 인해 미토콘드리아에서 활성산소인 과산소 라디칼 $\left(\mathrm{O}_{2}^{-}\right)$, 과산화수소 $\left(\mathrm{H}_{2} \mathrm{O}_{2}\right)$, 수산 라디칼 $(\mathrm{OH})$ 과 단 일 산소 $\left(\mathrm{O}_{2}\right)$ 등이 발생한다. 활성산소의 발생이 증가되 면서 호기성 생물체의 노화와 암 발생이 증진된다 ${ }^{[1]}$.

활성산소의 발생 기전은 산화계와 항산화계의 향상 성이 손실되었을 때 나타난다고 한다. 산화계와 항산 화계를 파괴하는 외부적 환경으로는 황화합물, 전리방 사선이나 hemoglobin, 제초제와 같은 산화환원 고리화 합물 등이 있으며 특히, 이중 전리방사선에 의해 발생 되는 활성산소는 거의 단백질 변형을 동반하기 때문 에 세포의 노화촉진과 치사율을 증가시키는 결과를 나타낸다 ${ }^{[2]}$.

활성산소는 항산화제인 비타민E, 비타민C등과 Superoxide dismutases(SODs), Catalase and Peroxidase, glutathione 와 같은 몇 가지 항산화 효소 및 항산화물 질에 의해서 소거된다고 한다. 진핵세포는 세포질에 $\mathrm{Cu} \mathrm{ZnSOD}$ 와 미토콘드리아 매트릭스에 SODs, Mn $\mathrm{SOD}$ 의 두 가지 형태를 포함하고 있다 ${ }^{[3]}$.

free radical는 DNA, RNA, 단백질, 지방 등에 화학반 응으로 강하게 작용하여 고분자들의 구조와 기능이 변형되며 그에 따른 세포소기관의 형태 및 기능의 변 화가 일어나고 이로 인해서 세포의 노화 및 치사가 발 생한다고 많은 학자들의 보고하고 있다 ${ }^{[4],[5]}$.

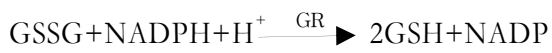

Ginseng(Panax Ginseng C.A Meyer의 뿌리)는 5000년 보다 더 이전에서부터 중국의학에서 사용된 수많은 천연 약물 중 하나이다. 그 후 한국, 일본으로 전달되 어 약초로서 사용되어 왔다. 인삼은 보혈, 강장, 항암, 항산화작용 ${ }^{[6]}$ 등으로 사람에게 유익하다는 내용은 중 국 최고의 약물서 “신 농본초경”에 의해서 보고되어 왔다.

고려인삼은 원산지가 중국 동북부, 극동 시베리아, 대한민국 산간부에 분포하는 오가과(五加科)의 다년생 초본이다. phenol계 유기산과 지방산은 인삼에 존재하 고 있어 항산화효과를 가지고 있다고 하며, 특히 알코
올이나 ethyl ether,물과 같은 용매로 추출한 인삼성분 중 사포닌은 항산화, 지질성분에 계면활성을 나타내어 소화 흡수작용을 증진시킨다고 한다.

골수에 보혈작용으로 방사선조사 시 방사선 방호효 과가 있음이 알려져 있다.

동충하초는 겨울에는 곤충의 몸에 있다가 여름에는 풀처럼 나타나는 자실체로서 자낭균강의 맥각균목 동 충하초과에 속하며 곰팡이균이 곤충에 침입하여 곤충 을 죽게 한 다음 기주로부터 자좌를 형성하는 버섯을 말하며 한국을 비록하여 중국, 일본 등에 널리 분포하 고 있다.

자좌를 형성하는 동충하초의 대부분은 자낭균강 맥 각균목 맥각균과에 속하는 Cordyceps 속, Torrubiella 속 등이 있는데 대표적인 속은 Cordyceps 속이다.

지금까진 알려진, 곤충에 침입하는 곰팡이균은 약 800 여종으로, 이들 중 버섯을 형성하는 자낭균류의 종 충하초에 속하는 균으로는 약 300 여 종이 보고되었으 며, 한국에는 번데기동충하초 ${ }^{[7,8\}}$ 등 현재까 균76종이 있으며 동충하초의 기주에는 누에, 벌, 매미, 나비, 풍 뎅이 및 이들의 애벌레, 번데기, 유충 등 종류가 매우 다양하다.

동충하초의 효능 ${ }^{[8]}$ 에는 중국 고서 본초종신에 폐를 보하고 신을 이롭게 하며 피를 거치게 하고 가래를 삭 이며 결핵성 기침을 치료할 수가 있다는 기록이 있다.

특히, 항균효과, 항종양효과, 혈당강화효과, 항피로 효과. 방사선방호효과 ${ }^{[9,10,11]}$ 가 보고되고 있다.

본 논문에서는 전신 $\mathrm{X}$ 선 조사 전 백삼 추출물과 동 충하초 추출물의 경구투여가 ICR mice 간에서의 방사 선 장해에 대한 방사선 방호효과를 구명하기 위하여 방사선방호제인 glutathione 함량변화에 미치는 영향을 예측 가능한 관계에 관련된 더 많은 정보를 얻기 위하 여 전신 X선 조사 후 2주간 연구했다. 


\section{II. 실험재료 및 방법}

\section{1. 실험재료}

\section{1) 실험동물}

4 주령된 ICR계 수컷 생쥐를 Shizuoka 실험동물센터 (Shizuoka, Japan)로 부터 구입하였다. 쥐는 약 $50 \pm 10 \%$ 의 상대습도와 실온 $20 \pm 2{ }^{\circ} \mathrm{C}, 12$ 시간 명암주기의 우리 에서 시판되는 생쥐용 사료와 물을 자유롭게 먹게 하 였으며, 이와 같은 조건에서 1주일간 적응시킨 후 체 중이 25-30 g의 생쥐만을 선별하고 각 실험군으로 분 류하여 사용하였다.

\section{2) 시약}

Glutathione reductase, $\beta-N A D P H$, Phosphoric acid, potassium phosphate monobasic, potassium phosphate dibasic, ethylenediamine tetraacetic acid(EDTA) 등은 Sigma로부터 구입했다. $\mathrm{Na}_{2} \mathrm{CO}_{3}$ 등은 기타 시약들은 일 반 특급시약을 사용하였다.

\section{3) 인삼추출물 및 동충하초추출물}

백삼 뿌리의 추출물은 일화(주) 중앙연구소로부터 얻었고 실험동안에 섭씨 4도에서 저장했다. 인삼추출 물을 $0.9 \% \mathrm{NaCl}$ 용액에 용해시키고 남은 부스러기는 15 분 동안 $600 \mathrm{~g}$ 를 윈심 분리를 한 후 버렸다. 깨끗한 상징액은 투여액으로 사용했다.

동충하초추출물인 Paecilomyces japonica(누에번데기) 는 임실동충하초 연구소에서 재배되어 건조시키고 분 발상태로 제공받았으며, $5 \mathrm{~g}$ 를 내열용기에 넣고 물을 채워 $100 \mathrm{~m} \ell$ 로 한 후 고압증기(압력: $1.2 \mathrm{~kg} / \mathrm{daycm}$ )로 $120{ }^{\circ} \mathrm{C}$ 에서 6시간 추출하였다. 추출물을 냉각하고 여 과 한 후 여액에 물을 이용하여 $100 \mathrm{~m} \ell$ 로 정용하여 동 충하초 추출물로 사용했다.

\section{4) 실험동물 처리}

방사선 방호효과를 검토하기 위하여 <Table> 1 과 같이 실험동물인 생쥐 5 마리를 1 군으로 하여 대조군
(Con), 방사선조사군(Rad), 백삼(WG+Rad) 투여군, 동충 하초(EF+Rad) 투여군 등 총 4 개 군으로 분류하였다. 대조군, 방사선조사군은 증류수 $0.1 \mathrm{ml} / \mathrm{day}$ 를 경구 투 여하였고, 백삼투여군은 방사선조사 전에 7 일 동안 $150 \mathrm{mg} / \mathrm{kg} / \mathrm{day}$ 을 쥐에 경구 투여하였다.

또한, 동충하초 투여군은 방사선조사 전에 7일 동안 $200 \mathrm{mg} / \mathrm{kg} / \mathrm{day}$ 을 쥐에 경구 투여하였다. 방사선조사는 $6 \mathrm{Mev}$ X선원을 이용하여 $5.0 \mathrm{~Gy}(1.01 \mathrm{~Gy} / \mathrm{min})$ 의 선량을 1 회 전신조사 하였다.

\section{5) 실험기기}

원심분리기(Beckman J2-2401PC), 마쇄기(wheaton USA), 분광광도계(Shimadzu UV-2401PC), 초저온 냉동 기(Ilsin DF9007), 증류수 제조기(MILLIPORE Milli -Q), 제빙기(BREMA HB802), 저울(METTLER AT201), 초음 파 마쇄기(BRANSON 3210) 및 항온수조(EYELA, $\mathrm{SB}-9)$, Linac $6 \mathrm{Mev}$ X선 치료장치(NEC model)등을 사용 하여 실험하였다.

\section{6) 분석시료 제조}

대조군과 $6 \mathrm{Mev} \mathrm{X}$ 선 조사 후 4시간, 24시간, 7 일, 14 일에 동충하초 투여군 $(\mathrm{EF}+\mathrm{Rad})$, 백삼 추출물 투여군 (WG+Rad) 과 방사선조사군 $(\mathrm{Rad})$ 을 각각의 실험군당 20 마리씩 16시간 절식시킨 다음 경추탈구로 희생 시키 고 간을 적출 한 후 얼음결정이 있는 상태의 생리식염 수에 넣어 세절하고 세 번 수세하여 혈액을 제거하고 무게를 측정하였다.

신선한 쥐 간(약 $1.0 \mathrm{~g})$ 는 Sucrose/EDTA/EDTA (0.25 M/ $1 \mathrm{mM}$ ) 용액을 넣고 마쇄기(glass teflon homogenizer)로 분쇄하여 $10 \%$ 균질액을 만들었다. 이 균질액 을 1 차 원심분리로 15 분 동안 $600 \times \mathrm{g}$ 에서 실시하고 상 등액을 취하고, 이 상등액을 2 차 원심분리로 10 분 동 안 $900 \times \mathrm{g}$ 에서 실시하였다. 


\section{2. 실험방법}

\section{1) 방사선조사 및 투여 용법}

수컷 쥐 (무게 25 30 g)는 균등한 조사야 $20 \mathrm{~cm} \times 20$ $\mathrm{cm}$ (선량율 $1.01 \mathrm{~Gy} / \mathrm{min}$ )로 $\operatorname{Linac} 6 \mathrm{Mev}$ X선 치료 장치 (NEC model)을 이용하여 각각 $5 \mathrm{~Gy}$ 씩 실온에서 전신 조사 했다.

[Table 1.] classification of experimental groups

\begin{tabular}{cccc}
\hline & & \multicolumn{2}{c}{ 처리방법 } \\
\cline { 3 - 4 } 실험군 & $\begin{array}{r}\text { 생쥐 } \\
\text { 마리수 }\end{array}$ & $\begin{array}{c}\text { 백삼투여군 및 } \\
\text { 동충하초투여군 } \\
(\mathrm{mg} / \mathrm{kg} / \mathrm{day})\end{array}$ & $\begin{array}{c}\text { 방사선조사선량 } \\
\text { (Gy/전신) }\end{array}$ \\
\hline \hline & 20 & - & - \\
대조군 & 20 & - & 5 \\
방사선조사군 & 20 & 150 & 5 \\
백삼투여군 & 20 & 200 & \\
동충하초투여군 & 20 & & \\
\hline
\end{tabular}

대조군 : 생리적 식염수 $(0.1 \mathrm{ml})$ 를 경구투여 했다.

방사선조사군 : $5 \mathrm{~Gy}$ 의 방사선조사 전 7일 동안에 생리적 식염 수 $(0.1 \mathrm{ml})$ 를 경구투여 했다.

백삼투여군 : $5 \mathrm{~Gy}$ 의 방사선조사 전 7일 동안에 생리적 식염수 $(0.1 \mathrm{ml})$ 와 백삼를 경구투여 했다.

동충하초투여군 : $5 \mathrm{~Gy}$ 의 방사선조사 전 7일 동안에생리적 식

염수 $(0.1 \mathrm{ml})$ 와 동충하초를 경구투여 했다.

인삼 추출물는 $5.5 \mathrm{mg} / 0.1 \mathrm{ml}$ 의 농도로 생리학적 식 염수에 용해했고 체중 $15 \mathrm{mg} / 100 \mathrm{~g}$ 의 양에서 쥐에 경 구 투여했다. 또한, 동충하초투여군 $(\mathrm{EF}+\mathrm{Rad})$ 은 방사선 조사 전에 7일 동안 $200 \mathrm{mg} / \mathrm{kg} / \mathrm{day}$ 을 쥐에 경구 투여하 였다.각 실험군은 보통 20 마리의 쥐로 구성되었다. 실 험 디자인은 <Table $1>$ 과 같다. <Table 1 >과 같이 실험 동물로 20 마리를 1 군으로 하여 대조군(Con), 동충하초 투여군 $(\mathrm{EF}+\mathrm{Rad})$, 방사선조사군 $(\mathrm{Rad})$, 백삼투여후 방사 선 조사군(WGE+Rad)등으로 4 개 군으로 분류하였다.

\section{2) Glutathione(GSH) 함량 측정}

간조직에서의 total glutathione(GSH $+\mathrm{GSSG})$ 와 GSSG함량은 Tietze 측정법을 변형한 Griffith(1980)방법 에 의해 측정하였다.
Total glutathione의 정량은 $0.3 \mathrm{mM} \mathrm{NADPH} / 0.125 \mathrm{M}$ 인산완충용액(containing $6.3 \mathrm{mM}$ EDTA, pH 7.5)700 $\mu$, $6 \mathrm{mM} \mathrm{DTNB}$ 용액 $100 \mu l, 200 \mu l$ 의 측정시료를 혼합한 반응액을 $30{ }^{\circ} \mathrm{C}$ 로 조절되는 thermostatted cuvette holder 에서 4 분간 안정화시킨 다음 $412 \mathrm{~nm}$ 에서 흡광도 변화 를 1 분간 측정하였다. GSSG의 정량은 $\mathrm{GSH}$ 를 제거하기 위해 측정시료와 acrylonitrile을 혼합하여 60 분간 방치한 후 total GSH와 동일한 조건에서 $\mathrm{GR}(200 \mathrm{kU} / \ell)$ 용액을 $20 \mu l$ 로 증가하여 반응시커 흡광도의 변화를 측정하였 다. GSH의 함량은 다음 식에 의해서 계산하였다.

$$
\mathrm{GSH} \text { 농도 }=\text { total GSH농도 }-2 \times[\mathrm{GSSG}]
$$

\section{3) 통계처리}

모든 실험결과에 대한 통계처리는 각 실험군별로 평균차이가 있는가를 검증하기 위하여 분산분석 (ANOVA)을 수행하였으며, 투여군 간의 유의성은 Student t-test을 이용하여 상호유의성을 검증하였다.

\section{III. 실험결과}

생리 식염수을 투여한 대조군(Con)과 방사선을 조 사한 방사선 조사군(Rad), 방사선 조사전 백삼을 투여 한 투여군(WGE+Rad), 동충하초투여군(EF+Rad)으로 각 실험군을 분류하여 실험을 실시한 결과로 활성산 소를 소거하는데 작용하는 방사선 방호제인 glutathione 의 함량변화 등을 아래와 같이 얻게 되었다.

\section{1. 백삼과 동충하초가 glutathione(GSH)함량에 미치는 효과}

\section{1) glutathione(GSH)의 함량 변화}

방사선조사로 인해 생성된 활성산소에 대한 백삼과 동충하초의 방호효과를 알아보기 위하여 인삼과 동충 하초를 전 처리한 다음 방사선을 조사한 후 $\mathrm{GSH}$ 의 함 량을 측정한 결과, < table 2>과 < Fig 1>에서 보는 바와 같이 방사선조사군의 GSH 함량이 대조군에 비해 유 의성 $(\mathrm{p}<0.01)$ 있게 감소하였다.

또한, 백삼과 동충하초 투여군의 경우 4시간째를 제 외한 1일, 7 일 및 14 일째에 모든 투여군에서 대조군에 
"Journal of the Korean Society of Radiology, Volume 6, Number 2"

비하여 그 함량이 유의성 $(\mathrm{p}<0.01)$ 있게 감소하였으나, 방사선조사군을 대조군으로 하여 인삼과 동총하초 투 여군의 상호 유의성은 모든 투여군에서 방사선조사군 에 비하여 $\mathrm{GSH}$ 의 함량이 유의성 $(\mathrm{p}<0.01)$ 있게 증가하 였다. 인삼 투여군과 동충하초 투여군 사이의 GSH 함 량에서 모두 상호 유의성 있는 결과는 보이지 않았다.

이러한 결과를 종합하여 볼 때 백삼과 동충하초는 방 사선조사로 GSH의 함량 감소를 유의성 있게 억제하여 생체 내에 방호작용을 원활하게 할 것으로 판단된다.

\section{2) 산화형 glutathione(GSSG)의 함량 변화}

GSH는 방사선조사로 생성된 유해한 과산화수소나 유기과산화물과 반응하여 황산화작용에 중요한 역할 을 한다. 이 반응을 촉매하는 효소인 GPx(glutathione peroxida se) 가 2 분자의 GSH와 공유결합 할 수 있도록 유도하여 1 분자의 GSSG가 생성하게 한다. 백삼과 동 충하초를 방사선조사 전에 경구투여 할 경우 과산화 수소로부터 생체 내에 조직을 보호하려는 백삼과 동 충하초의 방사선 보호효과 등을 검토하기 위하여 $\mathrm{GSSG}$ 의 함량변화를 측정하였다.

$<$ Table 3>와 < Fig 2>에서 보는 바와 같이 백삼과 동충하초를 방사선조사 전에 경구투여 하여 GSSG의 함량변화를 측정한 결과, 방사선조사군 $(\mathrm{Rad})$ 의 $\mathrm{GSSG}$ 의 함량변화는 4시간째를 제외한 1일, 7 일 및 14 일째 모두 대조군에 비하여 유의성 $(\mathrm{p}<0.01)$ 있게 함량이 증 가하였다.

또한, 백삼과 동충하초 투여군의 경우 4시간, 1 일째 에는 GSSG의 함량이 대조군과 거의 비슷한 함량 수준 을 보였으며, 특히 7일째, 14일째 백삼투여군 과 동충 하초 투여군에서 모두 함량 증가를 보였다.

방사선조사군 $(\mathrm{Rad})$ 을 대조군으로 하여 백삼 투여군 과 동충하초 투여군의 상호 유의성을 조사한 결과 4시 간, 1 일째에는 GSSG의 함량 수준이 방사선 조사군보 다 감소하였으나 유의성은 없었으며, 7일, 14일째에는 유의성 $(\mathrm{p}<0.01)$ 있게 감소하였다. 백삼 투여군 과 동충 하초투여군 사이의 상호 유의성은 없었다.
[Table 2] Effects of white ginseng and Entomopathogenic Fugi pretreatment on hepatic GSH contents of X-ray irradiated mice

\begin{tabular}{|c|c|c|c|c|}
\hline 시간 & \multicolumn{4}{|c|}{ GSH 함량 (umole/g 간) } \\
\hline 실험군 & 4시간 & 1일 & 7 일 & 14일 \\
\hline 대조군 & \multicolumn{4}{|c|}{$5.28 \pm 0.125 .18 \pm 0.115 .09 \pm 0.075 .07 \pm 0.24$} \\
\hline 방사선조사군 & \multicolumn{4}{|c|}{$4.30 \pm 0.344 .05 \pm 0.202 .81 \pm 0.43 \quad 3.01 \pm 0.48$} \\
\hline $\begin{array}{l}\text { 동충하초 } \\
\text { 투여군 }\end{array}$ & \multicolumn{4}{|c|}{$4.75 \pm 0.464 .36 \pm 0.394 .11 \pm 0.164 .49 \pm 0.33$} \\
\hline 백삼투여군 & \multicolumn{4}{|c|}{$5.04 \pm 0.304 .59 \pm 0.24 \quad 4.43 \pm 0.334 .73 \pm 0.23$} \\
\hline
\end{tabular}

[Table 3] Effects of white ginseng and Entomopathogenic Fugi pretreatment on hepatic GSSG contents of X-ray irradiated mice

\begin{tabular}{|c|c|c|c|c|}
\hline \multirow{2}{*}{$\begin{array}{l}\text { 시간 } \\
\text { 실험운 }\end{array}$} & \multicolumn{4}{|c|}{ GSSG 함량 (umole/g 간) } \\
\hline & 4시간 & 1일 & 7일 & 14일 \\
\hline 대조군 & $0.43 \pm 0.07$ & $0.45 \pm 0.04$ & $0.48 \pm 0.04$ & $0.43 \pm 0.05$ \\
\hline 방사선조사군 & $0.48 \pm 0.09$ & $0.52 \pm 0.05$ & $0.58 \pm 0.04$ & $0.62 \pm 0.06$ \\
\hline 동충하초 투여군 & $0.44 \pm 0.06$ & $0.46 \pm 0.05$ & $0.53 \pm 0.03$ & $0.51 \pm 0.03$ \\
\hline 백삼투여군 & $0.43 \pm 0.05$ & $0.46 \pm 0.02$ & $0.50 \pm 0.03$ & $0.47 \pm 0.04$ \\
\hline
\end{tabular}

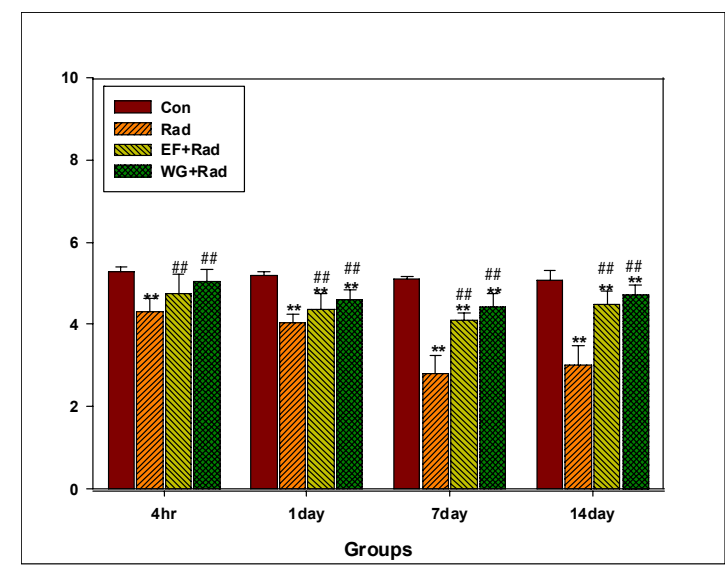

Fig. 1. Time-dependent change of GSH contents affected white ginseng, Entomopathogenic Fugi and post-irradiation. The values represent mean \pm S. D. $* p<0.05$ and $* * p<0.01$ : significantly different from control(Co) group. \#\#p<0.01 : significantly different from Rad group, WG + Rad group. EF + Rad group. 


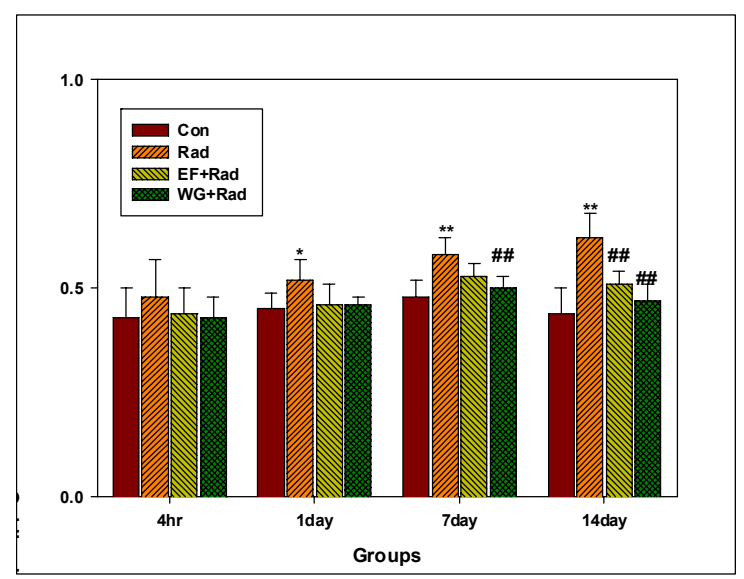

Fig. 2. Time-dependent change of GSSG contents affected white ginseng, Entomopathogenic Fugi and post-irradiation.

The values represent mean \pm S. D. $* p<0.05$ and $* * p<0.01$ :

significantly different from control(Co) group. \#\#p<0.01 : significantly different from Rad group, WG + Rad group. EF + Rad group.

\section{3) 산화형 glutathione(GSSG)/ total GSH 의 비율 변화}

GSSG/total GSH 비율은 방사선조사에 의해 생성된 유해한 과산화수소나 유기과산화물과 같은 지질과산 화의 정도와 조직세포의 장해에 직접 관련이 있으며, 생물체의 조직세포 내 산화환원반응에 따른 해독작용 체계를 평가하는데 중요한 지표가 된다. 그리고 활성 산소 생성의 정량적인 측정에 이용된다.

백삼과 동충하초를 방사선조사 전에 경구투여 할 경우 활성산소로부터 생체조직을 보호하는 인삼과 동 충하초의 방사선 보호효과를 검토하기 위하여 $\mathrm{GSSG} /$ total GSH의 비율 변화를 측정하였다.

[Table 4] Effects of white ginseng and Entomopathogenic Fugi pretreatment on hepatic GSSG/ total GSH .contents of X-ray irradiated mice

\begin{tabular}{|c|c|c|c|c|}
\hline \multirow{2}{*}{ 실험군 } & \multicolumn{4}{|c|}{ GSSG/총 GSH 함량비율 (\%) } \\
\hline & 4시간 & 1일 & 7일 & 14일 \\
\hline 대조군 & $8.38 \pm 0.80$ & $8.63 \pm 0.57$ & $8.95 \pm 0.55$ & $8.55 \pm 0.37$ \\
\hline 방사선조사군 & $10.55 \pm 0.37$ & $11.75 \pm 0.75$ & $17.15 \pm 0.98$ & $16.15 \pm 0.90$ \\
\hline 동충하초투여군 & $8.83 \pm 1.14$ & $10.11 \pm 1.10$ & $10.95 \pm 1.10$ & $9.35 \pm 1.27$ \\
\hline 백삼투여군 & $8.95 \pm 1.21$ & $10.35 \pm 1.53$ & $12.40 \pm 1.36$ & $10.70 \pm 0.61$ \\
\hline
\end{tabular}

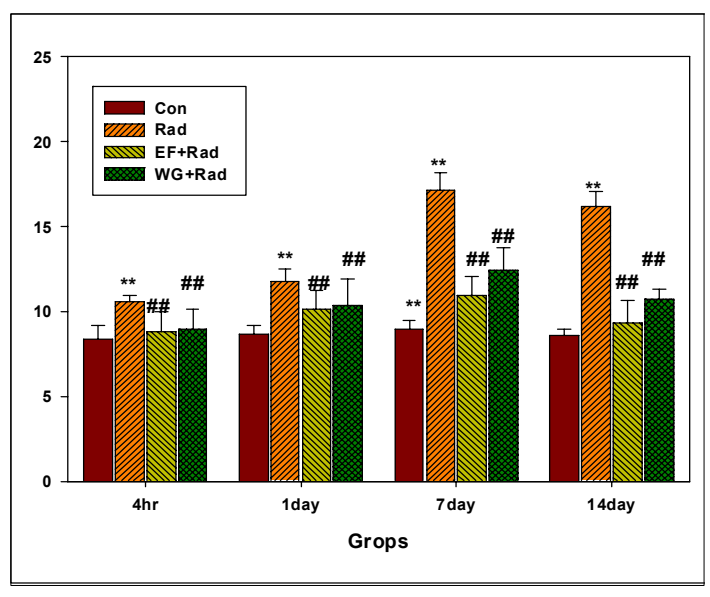

Fig. 3. Time-dependent change of GSSG contents affected white ginseng, Entomopathogenic Fugi and post-irradiation.

The values represent mean \pm S. D. $* p<0.05$ and $* * p<0.01$ : significantly different from control(Co) group. \#\#p<0.01 : significantly different from Rad group, WG + Rad group. EF + Rad group.

$<$ Table 4>와 < Fig 3>에서 보는 바와 같이 백삼과 동충하초 투여군의 경우 4시간째에 대조군에 비하여 비율이 약간 증가하였다가 1일, 7 일 및 14 일째 대조군 에 비하여 유의성 $(\mathrm{p}<0.01)$ 있게 비율이 증가하였다. 방사선조사군 $(\mathrm{Rad})$ 을 대조군으로 하여 백삼과 동충하 초 투여군의 상호 유의성을 조사한 결과 모든 투여군 에서 방사선조사군에 비하여 그 비율이 유의성 $(\mathrm{p}<0.01)$ 있게 감소함을 보였다. 또한, 백삼과 동충하초 투여군 사이의 상호 유의성을 조사한 결과 백삼투여 군이 1 일, 7 일 및 14 일째 동충하초투여군에 비하여 비 율이 증가함을 보였으나 유의성은 없었다. 이러한 결 과를 종합하여 볼 때 백삼과 동충하초 투여군은 방사 선조사군에 비하여 모두 GSSG/total GSH의 비율을 감 소시켰으며, 백삼과 동충하초 투여군 사이의 상호 유 의성은 없었다.

\section{$\mathrm{IV}$. 고 찰}

Hazelton 등 ${ }^{[12]}$ 이 노화에 따른 생쥐의 GSH 함량변화 를 측정한 결과 간, 신장, 심장등에서 점차 감소한다고 하였다. Speisky 등 ${ }^{[13]}$ 은 간 조직 중에서 $\mathrm{GSH}$ 의 고갈이 가능한 기전으로 항산화적 작용으로 소모 외에도 acetaldehyde와 GSH 결합, GSH의 간 내의 합성저하, 담 
즙으로 배설 증가, 혈액으로 유출 증가의 원인이라고 하였다. 동물조직 중에 nonprotein thiol의 대부분을 차 지하고 있은 환원형 글루타치온(GSH)은 생체 내의 활 성산소 소거제로 잘 알려져 있다. GPx에 의해 과산화 수소를 제거하면서 산화형(GSSG)으로 전환되고, GSSG는 glutathione reductase에 의하여 NADPH를 소모 하면서 다시 GSH로 환원되어 활성산소로부터 세포를 보호하는데 중요한 역할을 한다.

Vendemiale 등 ${ }^{[14]}$ 은 생체조직 중에 GSH의 결핍은 지질과산화 반응을 촉진시키며, GSSG/total GSH 비율 은 조직세포 내의 산화환원반응과 해독작용 상태의 평가에 중요하며, GSSG 형성은 활성산소 생성의 유용 한 정량적 지표가 되기 때문에 지질과산화 정도나 조 직 손상의 유발과 직접적으로 관련되어 있다고 하였 다.

방사선 유도에 의한 간 손상에 대하여 GSH는 GPx 항산화효소의 기질로 이용되면서 간 손상을 방어하는 아주 중요한 생체 내의 항산화물질로서 백삼과 동충 하초투여군이 GSH 생합성에 관여하는 효능을 조사한 결과, 대조군에 비하여 방사선조사군은 GSH의 함량이 감소한 반면 GSSG 함량은 증가하였다. 그러나 백삼과 동충하초 투여군은 방사선조사군에 비하여 GSH 함량 을 증가시켰으며, GSSG 함량은 감소시킨다고 하였다.

성 등 ${ }^{[15]}$ 은 GSH 및 GSSG/total GSH 비율의 증가에 대하여 홍삼 성분이 GSH 생합성을 촉진하고, 8 -glutamylcy steine synthetase 효소의 활성화 증대 및 glutathione reductase에 의해 다시 GSH로 원활하게 환 원시키며, $\mathrm{GPx}$ 의 활성증대로 생성된 $\mathrm{GSSG}$ 는 담즙이 나 혈액으로 배출시킬 것이라고 하였다.

그러나 이 등 ${ }^{[16]}$ 은 glutathione reductase의 활성이 홍

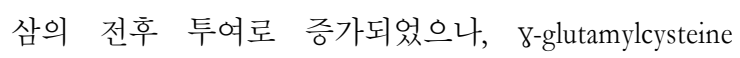
synthetase의 활성에는 별다른 영향이 없었다고 하였다. 또한, 곽 등 ${ }^{[17]}$ 은 ethanol에 중독된 흰쥐에서 담즙울체 가 간의 GST, GR, GPx 활성변화에 미치는 실험에서 급성 및 만성 ethanol 중독시 간에 담즙울체가 야기되 면 소포체의 GST와 세포질의 GR 활성이 간에 담즙울 체만 야기시켰을 때보다 그 활성이 감소하였으며, 간 의 세포질 분획의 GST는 GPx 활성이 증가하였다고 하였다.
전 등 ${ }^{[18]}$ 은 동충하초투여군에서 $\mathrm{GSH}$ 함량이 증가함 을 알 수가 있었으며 더 나아가 paraquat투여로 낮아지 는 GSH함량을 회복시킴을 보고하였다.

이러한 결과를 종합하여 볼 때 GSH의 함량 증가는 백삼과 동충하초의 활성성분이 GSH의 생합성효소의 활성을 증가시키기보다 glutathione reductase 효소를 활 성화함으로써 GSSG가 GSH로 환원되어 효능을 나타 내었기 때문이라고 여겨진다.

\section{$\mathrm{V}$. 결 론}

Linac $6 \mathrm{Mev} \mathrm{X}$ 선을 생쥐에 전신조사로 유도된 생쥐 간의 장해에 대한 백삼과 동충하초추출물의 방사선방 호효과를 방호제인 glutathione(GSH) 함량 변화를 통하 여 실험적 연구를 하였다.

ICR종 수컷 생쥐를 동충하초 투여군, 백삼 투여군, 방사선 조사군, 대조군으로 각각 분류하여 동충하초 투여군(EF+Rad), 백삼투여군(WG+Rad)은 Linac $6 \mathrm{Mev}$ $\mathrm{X}$ 선 조사 전에 백삼은 7일간 $(150 \mathrm{mg} / \mathrm{kg} /$ day), 동충하초 는 7일간 $(200 \mathrm{mg} / \mathrm{kg} / \mathrm{day})$ 을 각각 경구 투여하였고, 방 사선 조사군(Rad)은 $6 \mathrm{Mev}$ X선을 $5 \mathrm{~Gy}(1.01 \mathrm{~Gy} / \mathrm{min})$ 선량으로 조사하였으며, 대조군(Co)은 $0.1 \mathrm{ml}$ 의 생리적 식염수를 투여하였다. 각각의 실험군을 통하여 생쥐간 조직에서의 환원형 glutathione와 산화형 glutathione $(\mathrm{GSSG})$ 의 함량 변화를 조사한 결과 아래와 같다.

1. 동충하초투여군과 백삼 투여군에서 방사 선 조사 군보다 유의성 있게 glutathione 함량이 증가 하였고 산 화형 glutathione (GSSG)의 함량은 유의성 있게 감소하 였다.

2. 동충하초투여군과 백삼투여군에서 방사 선 조사 군 보다 산화형 glutathione (GSSG)의 함량과 총 glutathione함량 비율은 유의성 있게 감소하였다.

\section{Reference}

[1] Misra, H.P. and I. Fridovich., The generation of superoxide radical during the autoxidation of hemoglobin. J. Biol. Chem., Vol. 2, pp.6960-6962, 1992.

[2] Bannister, J. V. and G. Rotilio., Aspects of the structure, function and applications of superoxide dismutase. CRC., Vol. 22, pp.111-180, 1987. 
[3] Yonezawa, M., N. Katoh, A. Takeda, Reatoration of Radiation injury by ginseng $I$. some properties of the Radioprotective substance. J. of radiation research Vol. 22, No. 3, pp.336-343, 1981.

[4] Flohe, L. and Gunzler, W. A., Assays of glutathione peroxidase. Methods in Enzymology, pp.105, 1984.

[5] Griffith, O. W., Determination of glutathione and glutathione disulfide using glutathione reductase and 2-vinylpyridine. Analytical Biochem., pp.106-107, 1980.

[6] Hassan, H. M. and I. Fridovich,. Intracellular production of superoxide radicals and $\mathrm{H}_{2} \mathrm{O}_{2}$ by redox active compounds. Arch. Biochem. Biophys, Vol.17, pp.385 -395

[7] Packer, L,. Oxygen radical in biological system. Methods in Enzymology. Academic press, Vol. 2, pp.233, 1994.

[8] Yoo, B. H., Kim, O. J. and Kim, J. Y(1999), Radioprotective effects of Cordyceps sinensis extracts on r-irradiated mice. Vol. 22, pp.67. 1999.

[9] Chen, G. Z. and Chen, G. L,. Effect of Cordyceps sinensis on murine T-lymphocyte subset. chin. Med. J, Vol. 4, pp.104-109, 1991.

[10] Singh, A. and H. Singh,. Time-scale and nature of radiation -biological damage approaches to to radiation protection and post- radiation therapy. Prog. Biophy. Mol. Biol, Vol. 39, pp.66-107, 1982.

[11] Liu, Y., Wu, C. and Li, C,. Anti-oxidation of Paecilomyces sinensis. Chung Kuo Chung Yao Tsa Chih, Vol. 16, pp.256, 1991.

[12] Hazelton, G. A. and C. A. Lang., Glutathione Contents of tissues in the aging mouse. Biochem J., Vol. 25, pp.188, 1980.

[13] Speisky, H., Macdonald, A., Giles, G., Orrego, H. and Y. Israel,. Increased loss and decreased synthesis of hepatic glutathione after acute ethanol administration. J. Biochem., 225-565, 1985.

[14] Vendemiale, G., Altomare, E., Grattagliano I. and Albano, O, Increased plasma levels of glutathione and malondialdehyde after acute ethanol ingestion in humans. J. Hepatol, Vol. 9, pp.359, 1989.

[15] 성금수, 전철, 권용훈, 장재철, 홍삼 활성성분이 생쥐 간 조직에서 glutathione 및 지질과산화에 미치는 항산화 효과, 고려인삼학회지, Vol. 24, pp.29-34, 2000.

[16] 이화재, 김동윤, 장재철, Paraquat 투여 생쥐 간에서 홍삼추출 물의 항산 화효과, 고려인삼학회지, Vol. 23, pp.3, 1999.

[17] 곽춘식, 김여희, 조준승, ethano 중독흰쥐에서 담즙울체가
간의 glutathione, GST, GPx 활성변화에 미치는 영향, Korean Biochem, J Vol. 2, pp.23, 1990.

[18] 전철, 성금수, 권용훈, 장재철, 홍삼 활성성분이 생쥐 간 조직에서 glutathione 및 지질과산화에 미치는 항산화 효과, 고려인삼학회지,Vol. 24, pp.29-34, 2000. 